\title{
Research of Teaching Innovation on the Course of Water Resources Planning and Utilization
}

\author{
Baohui Men, Shanghong Zhang, Changming Ji, Cheng Zhang, Yanke Zhang \\ Renewable Energy Institute, North China Electric Power University, Beijing, China \\ Email: menbh@ncepu.edu.cn
}

How to cite this paper: Men, B. H., Zhang, S. H., Ji, C. M., Zhang, C., \& Zhang, Y. K. (2017). Research of Teaching Innovation on the Course of Water Resources Planning and Utilization. Creative Education, 8, 16941701.

https://doi.org/10.4236/ce.2017.810115

Received: May 18, 2017

Accepted: August 14, 2017

Published: August 17, 2017

Copyright $\odot 2017$ by authors and Scientific Research Publishing Inc. This work is licensed under the Creative Commons Attribution International License (CC BY 4.0).

http://creativecommons.org/licenses/by/4.0/

\section{Open Access}

\begin{abstract}
Objective: To innovate the teaching contents and teaching methods for the course of Water Resources Planning and Utilization which is one of the Hydrology and Water Resources Engineering professional 433 core courses of NCEPU. Methods: Literature review, modification of the course syllabus, textbooks, curriculum design task and construction of the professional teachers' team. Results: According to the basic requirements of the course construction of Water Resources Planning and Utilization, we have made some enrichment, expansion and necessary complements to the teaching contents. We have also tried to impart professional knowledge to students and to develop their practical abilities in the professional field of water resources. Gradually our undergraduate students are able to independently complete the summary of an academic paper, which includes their research methods, result analysis and conclusion drawing by writing their course papers. Conclusion: The innovation of the course of Water Resources Planning and Utilization is very successful by updating the content and changing the teaching method.
\end{abstract}

\section{Keywords}

Water Resources Planning and Utilization, Course Construction, Practical Teaching, Teaching Innovation

\section{Introduction}

Hydrology and Water Resources Engineering is the secondary discipline of water conservancy in NCEPU, following the setting of Water Resources and Hydropower Engineering, which was approved by the Ministry of Education in 2006 and its first session of undergraduate students was enrolled in 2007. The courses of the 2007 session of Hydrology and Water Resources Engineering were set up according to the 2006 Talents Cultivation Program. Water Resources Planning and Utilization was a compulsory course among these professional 
courses, and was arranged for 56 hours with 3.5 credits in this Talents Cultivation Program, without any practical instruction such as course exercise or practicum. In 2008, one year after the 2006 Talents Cultivation Program was implemented, and it began to be innovated and the 2008 version came into use. According to its fast-updating characteristic, the course of Water Resources Planning and Utilization was adjusted to 48 hours ( 3 credits) with an additional course exercise for one week ( 1 credit). In accordance with the new Talents Cultivation Program, NCEPU began to implement the plan of building 433 Core Courses, which consist of 4 public basic courses, 3 professional basic courses and 3 professional courses. Water Resources Planning and Utilization became one of the 433 Core Courses. After 2 years of construction, this course successfully passed the acceptance by the university, and now further construction and modification of this course is still on the way.

Water Resources Planning and Utilization is one of the major professional courses that the undergraduates take after studying the basic courses. It is indispensible in the studying of Hydrology and Water Resources Engineering.

There are two innovations proposed in this article. First, some questions about the teaching of this course have been discussed, such as lack of teaching hours, lagging-behind teaching content, strong interdisciplinary relations, and students having little desire to learn on their own initiative. Second, in order to solve these problems, some innovative attempts have been made in the teaching process, which include writing the textbook, changing the teaching approach, reforming the exam, and encouraging students to apply for innovation and entrepreneurship projects.

\section{Course Construction}

The course construction of Water Resources Planning and Utilization is carried out in the following facets: syllabus, textbook, curriculum design task and the professional teaching staff.

\subsection{Formulating of the Syllabus Formulation?}

According to the fundamental requirements of the 2008 Talents Cultivation Program, the feature of "Great Electric", which means most of the disciplines in this university should be based on electrical subjects, requires that Hydrology and Water Resources Engineering should serve as the basis for hydro-related courses. We have rewritten the syllabus of Water Resources Planning and Utilization on the basis of the 2006 version of training program. We have made some refinement and regulation of the nature of the course, the purposes and tasks of teaching, the basic requirements of teaching and the content of the course. The concept and approaches of water resources assessment are required to be grasped, including calculation and evaluation of the amount of surface water resources, groundwater resources analysis and evaluation, assessment of regional water resources and water quality, as well as approaches to water supply and demand analysis, a preliminary understanding of models and methods to op- 
timize water allocation and configuration, learning the basic theory, the experience and methods of modern management of water resources.

\subsection{Textbook Selection}

At present, the textbooks of Water Resources Planning and Utilization published in China are: 1) Water Resources Assessment and Management, edited by Qiwu Zhu and published by Yellow River Conservancy Press. This textbook is mainly edited in accordance with the national requirements and characteristics of Talents Training of the Higher Vocational College students. 2) Water Resources Assessment and Management, edited by Guixia Gao and published by China Water Power Press. This edition is adapted for specialized secondary school students. 3) Water Resources Assessment and Management, edited by Yanbin Li and published by China Water Power Press. This textbook covers the main content of water resources assessment and management, and utilization of water resources.

Some of the content of water resources assessment and management is also included in textbooks about Water Planning and Management, which mainly include: 1) Water Planning and Management, edited by Qiting Zuo and published by China Water Power Press. This textbook contains the content of water resources assessment, socio-economic development forecast, analysis of water resources systems, water resources planning and management. 2) Water Planning and Management, edited by Zengchuan Dong and published by China Water Power Press, which contains the concept, classification and characteristics of water resources, concepts and methods of water resources assessment, concepts of water demand forecasting, supply and demand balance analysis, optimal allocation of water resources, water system operation scheduling, integrated planning, management and sustainable use of water resources, etc. 3) National Integrated Water Resources Planning Technical Details, edited by Water Resources and Hydropower Planning and Design Institute, which is a good reference book for guiding the work of water resources planning and utilization (Dou, Zuo, \& Li, 2009). These textbooks involve a broader range, basically covering the relevant content of water resources planning and utilization. But for an undergraduate textbook, both the breadth and the depth of the content are necessary. What is even more critical is that the content should be able to reflect the latest technical methods or theories. In view of this, the authors of this article have edited the school textbook of Water Resources Planning and Utilization. This textbook highlights the practicality and up-to-date feature of this course, emphasizing that this course itself is constantly enriching and developing. The content of this textbook contains evaluation of the quantity and quality of water resources, the impact of water resources development and utilization on the environment, and comprehensive evaluation of water resources. It focuses on data preparation and procedures of evaluation. The new approaches for evaluation include 6 methods: matter element analysis method, fuzzy comprehensive evaluation method, attribute recognition method, principal component analysis 
method, improved gray correlation analysis, and information entropy method. In the chapter of water management, the newest relevant rules and regulations in our country are added, such as the most stringent regulation on water management (the "Three Red Lines" regulation). With the advances in science and technology, socio-economic development and improvement of people's living standards, especially the impact of global climate change and human activities on water resources, new methods of water resources assessment and new concepts about water resources management will continuously appear.

\subsection{The Curriculum Design Task Book}

According to the characteristic philosophy of NCEPU_"emphasize practice, strengthen ability"-and based on the design cycle time of 5 days in one week, the curriculum design task book of Water Resources Planning and Utilization was edited. The content contains the purpose and significance of curriculum design, basic data, curriculum design requirements and the schedule, among other design elements. Specifically, it includes hydrological data collection, collation and processing, calculation of water resources under different guaranteed rates, calculation of the amount of available ground (underground) water, calculation and forecasting of water demand in each department of national economy, analysis of the water supply and demand balance, and formulating the strategy and method of water resources management.

\subsection{Construction of the Faculty/Teaching Body}

After nearly six years of development, a teaching body of Water Resources Planning and Utilization has been built, consisting of 3 to 4 young teachers who are associate professors or above. With a doctorate and professional background in such subjects as Hydrology and Water Resources, Hydraulics and River Dynamics, Management Science and Engineering, our young teachers devote to the front-line teaching, so that we are able to get ideas and understanding about this course from teachers of different professional background, which makes the teaching more brainstorming and the effect of the practical teaching activity, such as the curriculum design, more notable.

\section{Problems in Teaching}

\subsection{Lack of Teaching Hours}

Our colleges and universities with the training objectives and requirements of "thick foundation, wide caliber, high capacity, high quality", have generally reduced the number of hours of professional courses (Huang \& Pan, 2009). Commonly 3 credits correspond to 48 hours, and it is rather hard to teach students the full details of the basic theory, the evaluation method and evaluation procedure of water resources assessment as well as the basic theory of water resources management. Besides, in their learning process, students will need a lot of extracurricular supplement to the basic knowledge, such as knowledge about economics for the teaching requirements of water price theory, knowledge about 
optimization theory and methods for the study of optimal allocation of water resources, and knowledge about hydrologic and hydraulic engineering calculation for the study of water quantity evaluation, etc.

\subsection{Teaching Content Lagging-Behind}

In the field of water resources planning and management, new theories, methods, technologies and norms continually emerge, while the textbook of professional course is usually used for a few years once selected, which inevitably leads to the occurrence of the teaching content lagging behind. It focuses on the traditional content explaining the basic principles and technical methods of water resources planning and utilization, and lacks introduction of new theories and technologies such as water safety assessment, development of water resources management information system and system construction, resulting in a situation where the knowledge students have acquired in the university is lagging behind the development of the subject at present.

\subsection{Strong Interdisciplinary Relations}

With the shortage of water resources, water issues have become increasingly prominent. The continuously rising degree of development and utilization of water resources makes water resources planning and utilization an increasingly interdisciplinary course with wide application, involving many aspects of water resources, such as water and the environment, water and ecology, water and economy, etc. In addition, with the development of scientific technology and applied technology especially computer technology, geographic information systems and " 3 " "technology, the tasks of water resources planning and utilization are becoming more and more complex and diverse.

\subsection{Students Have Little Desire to Learn Actively}

From the daily teaching process, we have noticed that students are just trying to remember some basic concepts, principles or equations in class, but not seeking to figure out corresponding strategies and methods for solving practical problems of water resources. They attend classes only/mostly for the questions in the final exams, which makes them have no desire to learn on their own initiative. They are only studying for good grades and are lacking in their own ideas and suggestions on current problems that arise in the fields of water resources, water environment and water ecology, as well as how to manage and make good use of water resources.

\section{Teaching Innovation}

To address the above problems that appear in the course of teaching, the authors are making some attempts on such aspects as the innovation of textbooks, the diversification of the teaching approach, the innovation of the exam and encouraging students to apply for innovation and entrepreneurship projects. 


\subsection{Textbook Innovation}

As mentioned above, the authors have edited a school textbook that involves new theories of and new approaches to water resources planning and utilization. For example, in the section about water demand forecast, Wetted perimeter method, Tennant method, and the flow duration curve method have been added to the calculation methods of the amount of water demanded in stream (Men \& Liu, 2013). In the section about water resources management, we have added the water rights theory as well as the "Three Red Lines" regulation in the most stringent water management theory adopted in 2011 in our country. We are making all these attempts in order to reduce the gap between the textbook and the practical work (Men \& Jin, 2016).

\subsection{Diversification of the Teaching Approach}

With the development of modern computer technology and graphics technology, especially the emergence of modern multimedia technology, modern teaching is gradually getting rid of the traditional "chalk + blackboard" teaching mode. Thus, it is advocated to actively use electronic handouts, electronic courseware, videos, images, and multimedia courseware in the teaching process, so as to better convey the basic concepts and principles, technology and methods which are abstract and hard to understand. The multimedia-formatted image is more graphical, making it easier for the students to understand, enhancing their interest in learning the professional course and arousing their curiosity, so that they will turn from "passive listening" to "active learning" (Men, 2014). Multimedia teaching, to a certain extent, makes up for the deficiencies of the existing teaching mode.

\subsection{Exam Innovation}

To avoid such a situation as students just memorizing concepts, principles and formulas to deal with the final exam, the traditional closed-book exam mode has been innovated into the writing of a course paper. The topic is either assigned by the teacher or chosen by students themselves. The course papers are required to be in a uniform format. The content needs to include a summary, an English abstract, the text and references. The summary must be within 200 to 300 words, and there should be 4 parts: research objectives, methods, results and conclusions. The amounts of references are required to be at least 20 to 30, half of which should be English literature. Through this sort of training, students are able to master the basic skill of writing an academic paper, and lay a solid foundation for dissertation writing. It also provides the necessary support for undergraduate students to participate in various competitions, or to publish academic papers.

\subsection{Encouraging Students to Apply for Innovation and Entrepreneurship Projects}

Due to the complexity, diversity and cross-cutting trait of water resources issues, 
in the teaching process we try to encourage students to think more and search for water-related problems that they can attempt to resolve. We have given guidance to more than 10 students on the knowledge of water and the environment, water and ecology, for their application for innovation and entrepreneurship projects (Men, Long, \& Zhang, 2016; Zhan, Men, Wu et al., 2015; Zhao, Men, Wang et al., 2014; Men, Long, Zhao et al., 2015; Li \& Men, 2016).

\section{Conclusion}

Based on the experience in teaching the course of Water Resources Planning and Utilization of Hydrology and Water Resources Engineering in North China Electric Power University, this article is about some innovative exploration of this 433 Core Course, in terms of syllabus formulation, textbook selection, teaching approach reformation, exam reform and how to encourage students to engage in innovation and entrepreneurship projects. According to the basic requirements of the course construction, we have made some enrichment, expansion and necessary complements to the teaching contents. We have also tried to impart professional knowledge to students and to develop their practical abilities in the professional field of water resources. Gradually our undergraduate students are able to independently complete the summary of an academic paper, which includes their research methods, result analysis and conclusion drawing, by writing their course papers.

\section{Foundation Item}

Famous Teachers Cultivation Planning for Teaching of North China Electric Power University (the Fourth Period).

\section{References}

Dou, M., Zuo, Q. T., \& Li, G. Q. (2009). Construction and Teaching of Water Resources Planning and Management Course. Researches on Higher Education, 18, 91-94.

Huang, J., \& Pan, F. K. (2009). Discussion “Water Utilization and Protection” Course Teaching Reform. Chinese Science and Innovation Herald, 11, 162.

Li, B. W., \& Men, B. H. (2016). Study on the Feasibility of Karst Water as a Source of Water Supply in Beijing. Nature Environment and Pollution Technology, 15, 135-140.

Men, B. H. (2014). Exploring the Hydrology and Water Resources Engineering Speciality System of North China Electric Power University. Advanced Materials Research, 1051, 616-621. https://doi.org/10.4028/www.scientific.net/AMR.1051.616

Men, B. H., \& Jin, J. L. (2016). Water Resources Planning and Utilization. Beijing: China Electric Power Press.

Men, B. H., \& Liu, C. M. (2013). Instream Ecological Water Demand Computing Ecosystem Hydraulic Radius Model and Its Application. Beijing: China Electric Power Press.

Men, B. H., Long, R. S., \& Zhang, J. H. (2016). Combined Forecasting of Streamflow Based on Cross Entropy. Entropy, 18, 336. https://doi.org/10.3390/e18090336

Men, B. H., Long, R. S., Zhao, Y. W., Wang, A. Z. et al. (2015). Correlation Analysis and Forecasting Changes in Yongding River Water Quality. Nature Environment and Pollution Technology, 14, 655-661. 
Zhan, S. G., Men, B. H., Wu, J. J. et al. (2015). Study on Urban Flood Control and Drainage in Beijing. Advanced Materials Research, 1065-1069, 2381-2385.

Zhao, Y. W., Men, B. H., Wang, A. Z. et al. (2014). The Fuzzy Comprehensive Evaluation of Water Quality Based on Weighted Modified in Beijing Garden Show Park. Nature Environment and Pollution Technology, 13, 517-521.

\section{Scientific Research Publishing}

Submit or recommend next manuscript to SCIRP and we will provide best service for you:

Accepting pre-submission inquiries through Email, Facebook, LinkedIn, Twitter, etc. A wide selection of journals (inclusive of 9 subjects, more than 200 journals)

Providing 24-hour high-quality service

User-friendly online submission system

Fair and swift peer-review system

Efficient typesetting and proofreading procedure

Display of the result of downloads and visits, as well as the number of cited articles Maximum dissemination of your research work

Submit your manuscript at: http://papersubmission.scirp.org/

Or contact ce@scirp.org 